Bijdragen tot de Dierkunde, 52 (2): 121-136 - 1982

\title{
PETRUS CAMPER'S STUDY OF THE JAVAN RHINOCEROS (RHINOCEROS SONDAICUS) AND ITS INFLUENCE ON GEORGES CUVIER
}

\author{
by \\ L. C. ROOKMAAKER \& R. P. W. VISSER \\ Biobistorical Institute, University of Utrecht, Nieuwe Gracht 187, \\ 3512 LM Utrecht, The Netherlands
}

\begin{abstract}
It has been asserted that Petrus Camper (1722-1789) was the first to distinguish the Javan Rhinoceros as a separate species. This opinion is based on a cursory remark in a posthumously published letter to the Russian scientist Peter Simon Pallas. A careful analysis of Camper's numerous writings on the rhinoceros, both published and unpublished, has produced not the slightest confirmation of this taxonomic achievement. Therefore, it seems premature to label Camper as the discoverer of the Javan Rhinoceros. As Georges Cuvier made ample use of the material collected by Camper, we have also discussed its influence on Cuvier's ideas with respect to rhinoceros classification.
\end{abstract}

\section{RESUME}

L'idée que c'est Petrus Camper (1722-1789) qui fut le premier à voir dans le Rhinocéros de Java une espèce distincte est généralement acceptée. Cette opinion est fondée sur une remarque fugitive dans une lettre adressée au zoologiste russe Peter Simon Pallas, lettre publiée après la mort de Camper. Mais une analyse sérieuse des nombreuses contributions de Camper, publiées ou non, sur les rhinocéros, n'a pas apporté la moindre preuve à l'appui de cette idée, et il semble prématuré de considérer Camper comme découvreur du Rhinocéros de Java. Puisque Georges Cuvier avait amplement utilisé le matériel collectionné par Camper, les auteurs s'occupent aussi de l'influence de ce dernier sur les idées de Cuvier concernant la classification des rhinocéros.

\section{INTRODUCTION}

In the course of the 18th century it had become customary to distinguish a single-horned rhinoceros in Asia and a double-horned species in Africa (Rookmaaker, 1981, 1982). While the status of these forms was discussed, there was before 1790 no suggestion at all about the possible existence of more living species of rhinoceros. It is therefore rather surprising to find the following remarks in a letter written by Petrus Camper (1722-1789), Dutch anatomist and paleontologist, published by Peter Simon Pallas in 1793:
"Ich habe Gelegenheit gehabt die beiden asiatischen Gattungen von Rhinoceros aus einander zu setzen, die mit vier grossen Schneidezähnen, zwey in jedem Kinnbacken versehen sind. Ich werde der Akademie zu Petersburg die Fortsetzung meiner Abhandlung von diesem Tier schicken" (Camper, 1793: 249).

This statement is both intriguing and tantalizing. It seems quite clear that Camper here distinguished two species of rhinoceros in Asia, which must refer to the animals now known as the Great Indian Rhinoceros (Rbinoceros unicornis Linnaeus, 1758) and the Javan Rhinoceros (Rbinoceros sondaicus Desmarest, 1822). 1 We are disappointed, however, if we try to find more information about his distinction of two Asian species. The article announced in the letter to Pallas never appeared in print anywhere. It is generally accepted that Camper's death, in 1789, prevented him to carry out his plan. It is this interpretation which Pallas gave in a footnote to Camper (1793: 249n), and subsequently subscribed to by Cuvier (1806: 32, 1812b: 14), De Blainville (1817: 165, 1846: 69), 2 Geoffroy St. Hilaire \& F. Cuvier (1824: 1), Schreber (1835: 309) and Müller \& Schlegel (1845: 183). 3 More recently, Sody (1959: 132) reviewed the problem and concluded that thanks to Camper "das Erkennen des Javaners als neue Art war damit vollzogen, aber u.a. durch das Fehlen eines 'Iateinischen' Namens blieb diese Entdeckung noch einigermassen in der Schwebe." Sody still leaves place for doubt, more than his followers Guggisberg (1966: 114) and Schenkel \& Schenkel-Hulliger (1969: 98).

It seems rather hasty to present Camper as the 


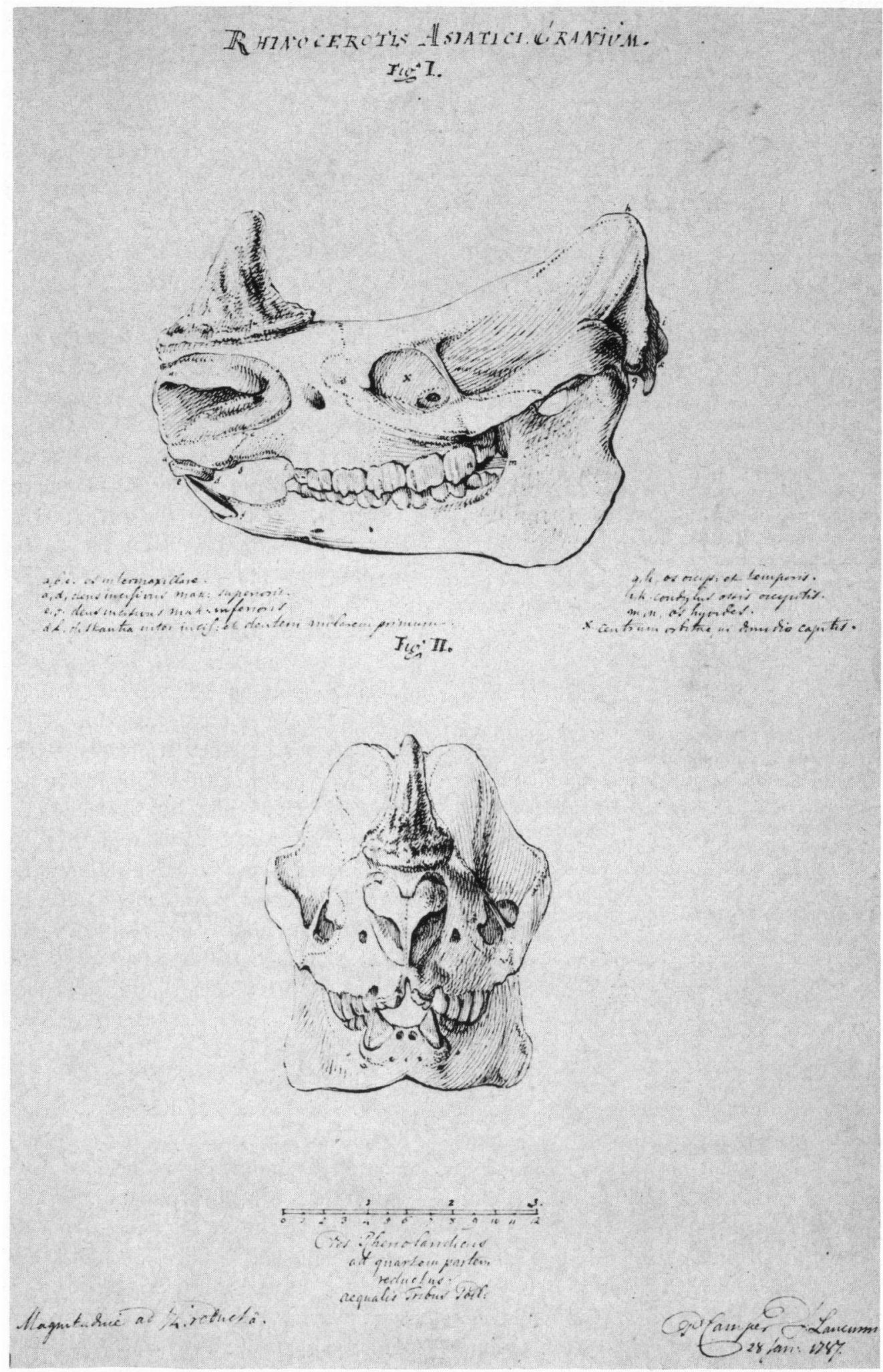

Fig. 1. Two views of the "Asian thinoceros" sent from Java to Camper in 1785. These drawings were later engraved by Vinkeles (see section 8) on a plate intended to show the differences between the African and Asian rhinoceroses. (Library of the University of Leiden, department of manuscripts, BPL $247 \mathrm{I}$ omslag 20.) 
discoverer of the Javan Rhinoceros just on the basis of the passage cited above, as there is nothing else pertinent to this subject in Camper's published oeuvre. To shed some light on this vexed question, it is necessary to turn to Camper's unpublished manuscripts, letters and drawings hoping to find additional remarks on the classification of the rhinoceros. We shall confine this discussion to the years after 1782, the year in which Camper published his major monograph on the African rhinoceros.

\section{FIRST REPORTS ON THE RHINOCEROS OF JAVA}

The first tolerable description of the rhinoceros on Java was given by Jacobus Bontius (15961631) who lived in Batavia during the last four years of his life. His observations on the rhinoceros or "Abada" were first published posthumously in 1642 and later included in the better known book edited by Piso (1658: 50-52). 4 Bontius observed the rhinoceros "a thousand times, caged, or grazing in the woods." His description is unsuitable, however, to indicate that the rhinoceros on Java would differ in some respects from the Indian species. The account in Piso (1658) is illustrated by two drawings, the lower one depicting the animal's head "Cranium Rhinocerotis", which was sent by Bontius (Piso, 1658: 52). The other figure above the first, showing a side view of the animal, was added by Piso and copied from a sketch "drawn after life in the Indies" which was supplied by Johannes Uutenbogaert (1557-1644).5 Sody (1959: 127) recognized the head as one of the Javan Rhinoceros, while the other figure "kann nicht als $R b$. sondaicus anerkannt werden." Whatever their diagnostic value, these figures are certainly original and they show at least one element attributable to the Javan species, i.e. the typical "saddle" formed by the neck folds on the withers. 6

In the century that followed, the presence of a rhinoceros on Java was asserted rather frequently, as shown by the review in Sody (1959: 128-131). There were, however, few original descriptions and nobody suggested even in the vaguest terms that there could be a difference between the rhinoceros of India and that of Java.

\section{CAMPER'S COLLECTION ABOUT 1780}

Until the end of the 18th century, European collections rarely included any rhinoceros parts except horns. Camper was probably exceptional in having a more varied collection, which in 1782 consisted of six specimens:

1, 2. The skull and skin of the head of a doublehorned rhinoceros, Diceros bicornis (Linnaeus, 1758), received from the Cape of Good Hope in 1771. They were presented by Joachim Annema, Baron van Plettenberg (1739-1793), who became Independent Fiscal at the Cape in 1767 and succeeded Rijk Tulbagh as governor in 1771 (Picard, 1972). Camper expressed his gratitude about this rare and valuable present on 18 August 1771. 7

3. The "nasal bone of a Cape rhinoceros", with a forward inclined anterior horn oi $2 \mathrm{t} / 2$ feet and a posterior horn of 10 duym Rijnlands length (Camper, 1782: 151). 8

4. The "nasal bone with two horns of a very young Rhinoceros" bought in Paris in 1777. The horns measured $61 / 2$ and $23 / 8$ duym, respectively (Camper, 1782: 152).

5. The "anterior part of the nose of an African rhinoceros with two horns", 25 and 6 duym long, respectively (Camper, 1782: 152).

6. The skull of a very young single-horned rhinoceros received from the "often praised" Mr. Hoffmann of Batavia (Camper, 1782: 166). 9 Its (occipito-nasal) length was some $30 \mathrm{~cm}$, which indicates that it belonged to a very young individual. Camper (1782: 166-167) described its dentition, saying that the anterior part of the upper jaw showed two sockets, "of which the anterior one was much larger than the one next to it." Similarly, the lower jaw had a tooth on both sides in front of the molars.

Besides, Camper studied the existing literature, previously published illustrations, $\mathbf{1 0}$ and rhinoceros specimens in other Dutch collections. The latter consisted primarily of horns, with two exceptions: a mounted skin of a very small rhinoceros in the museum of the Prince of Orange (Camper, 


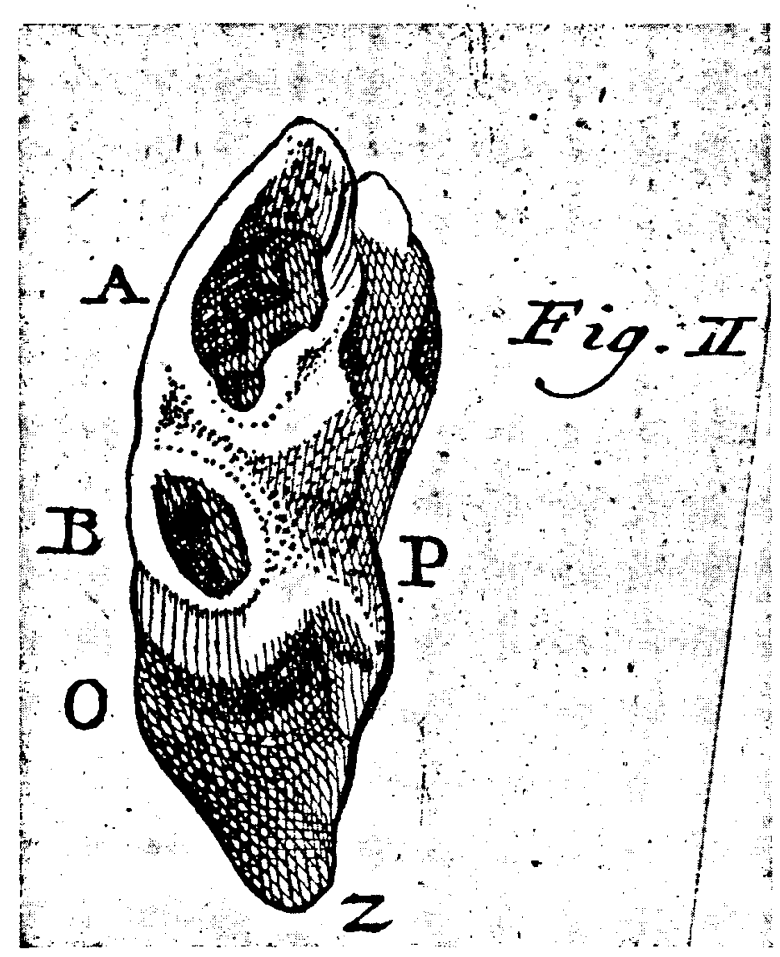

Fig. 2. Anterior part of the upper jaw of the immature skull of a Javan thinoceros (Rbinoceros sondaicus) in Camper's collection (no. 6), published by Pallas (1780, pl. IX fig. II).

1782: 154) and part of the lower jaw of a large rhinoceros in the collection of the University of Leiden (Camper, 1782: 167). ${ }^{11}$ Camper also observed two living specimens of the Indian rhinoceros. The first he saw in Leiden where he made a clay model and some drawings (Camper, 1782: 139, 147, 176; Rookmaaker, 1973: 50, fig. 9, 1978a). The second specimen he drew on 28 July 1777 in the menagerie of Versailles (Camper, 1782: 147). 12

\section{CAMPER'S CLASSIFICATION IN 1782}

In 1776 , Camper wrote a Latin description of his African specimens (nos. 1, 2), which appeared in the "Acta" of the St. Petersburg Academy in 1780 , illustrated by plates V to VIII. In the same issue, plate IX (figs. II, III) depicts the intermaxillary of the Javan skull (no. 6) and the anterior part of its lower jaw (figs. 2, 3). Although these figures were engraved after drawings made by Camper, the plate is discussed in a short note written by Pallas (1780), who clearly is responsible for its publication. ${ }^{13}$ Camper's major

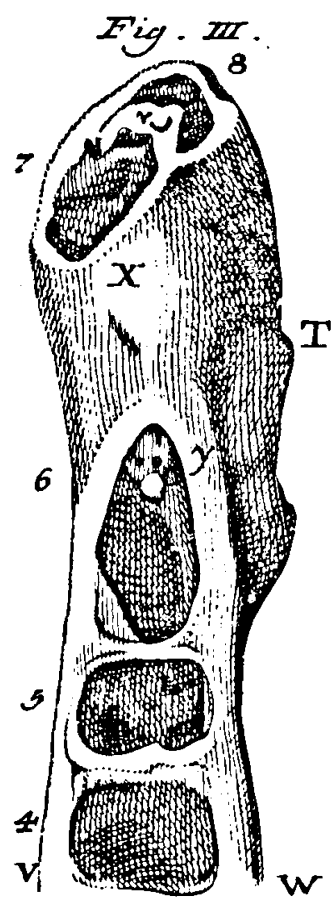

Fig. 3. Anterior part of the left lower jaw of the immature Javan rhinoceros skull (no. 6), published by Pallas (1780, pl. IX fig. III).

work on the rhinoceros appeared in Dutch in 1782. It is not merely a description of the African head and skull, but a review of the existing information about the rhinoceros in general. This monograph was translated into German in 1791 and into French in 1803. In the German edition there are a few footnotes (pp. 50, 59 and 61) in which some additional remarks written by Camper before his death are presented for the first time in print. 14

After examination of the material mentioned in the previous section, Camper decided to distinguish two species of thinoceros:

“I. Das Asiatische mit einem einzelnen runden Horne, und mit merklichen Falten und Schildern über den Körper, so wie Parsons, Albin und Buffon sie vorgestellt haben. 15

II. Das Afrikanische mit zwey platten Hörnern, einem hinter dem andern, ohne Falten oder Schilder."

(Camper, 1791: 61, cf. Camper, 1782: 180). 
The only characters used by Camper in this classification are the number of horns and the folds in the skin. Another important difference between the African black rhinoceros and the two single-horned species in Asia (genus Rbinoceros) is the presence of incisors in the latter. 16 Camper (1782: 167-169) observed these front teeth in the lower jaw of the Versailles specimen, and he mentioned them in his description of the young Javan skull, no. 6 above. He was reluctant, however, to include the absence or presence of incisors in his diagnosis, probably for two reasons.

First, Camper (1782: 169) realized that his material was insufficient. He had one African skull in which the intermaxillaries might have been damaged. Camper (1782: 165) stated to have preserved them with difficulty, while Merck (1786: 7) found them missing in Camper's specimen. The Asian skull (no. 6) belonged to a very young specimen, which obviously made comparisons with the adult African skull rather hazardous.

The second uncertainty is found in the observations by Pallas $(1769,1780)$ on fossil skulls. All rhinoceros skulls examined by Pallas were double-horned and Pallas maintained in his letters to Camper that there were always at least vestiges of sockets in the front part of the lower jaw in the fossil material (Camper, 1782: 166).

In 1782, Camper asked himself this question: "Maybe there is a constant difference [concerning the teeth] between the double-horned and the single-horned thinoceroses?" (Camper, 1782: 168, translated). More specimens were needed to answer this problem.

\section{JOURNEY TO ENGLAND IN 1785}

In 1785, Camper went to England for some months, during which time he kept a diary, published and translated by Nuyens (1939). He visited the British Museum several times. On 11 October 1785 he examined "several heads of thinoceroses from the Orient, and others from the Cape" (Nuyens, 1939: 175). 17 Although these skulls showed teeth in the anterior part of the lower jaw, they were too damaged in other parts (intermaxillaries were missing) to be useful (Camper, 1791: 50). Camper was much more pleased when he discovered in the collection of John Hunter (1728-1793) on 16 October 1785 "a head of an old rhinoceros from Asia, in whose upper as well as lower jaws there are very clearly incisors" (Nuyens, 1939: 182). He even returned to Hunter on 21 October to examine the specimen more thoroughly and to make some drawings of it (fig. 4). 18

\section{NEW MATERIAL FROM JAVA}

Camper obtained some additional rhinoceros specimens from Jacob van der Steege (17461811), one of his former pupils, who became M.D. at the University of Groningen in 1772 and who worked as physician in Batavia from 1774 until 1788. According to notes in the posthumous German translation of Camper's monograph, Van der Steege sent to Camper a skeleton, four heads, a tongue and a penis (Camper, 1791: 50, 59). We shall try to define this material more precisely according to letters by Van der Steege to Camper, and those by Camper to Joseph Banks (1743-1820) in London.

7. A letter by Camper to Banks of 8 June 1786 mentioned the arrival of a complete skeleton: 19 "I received just now from the East Indies a skeleton of a young thinoceros from Java, in which the teeth are, of which I have described the sockets in the act. of St. Petersburg, viz. the four incisivi in the lower jaw and four in the intermaxillary bones, of which two only are persistent." Possibly, this ship. ment included a tongue "im Weingeist" because Camper (1791: 59) dated its arrival as the summer of 1786 . He may have been mistaken, however, because on 1 October 1787 Van der Steege 20 wrote that he was sending "the tongue of the small Rhinoscer of which you have the skeleton and was forgotten to be sent at that time."

8. On 16 November 1785 , Van der Steege wrote to Camper that he was sending the head of a rhinoceros. 21 Camper was expecting this specimen on 8 and 18 June 1786, as he mentioned to Banks. 22 It probably arrived in the middle of summer 1786. 23 This shipment may also have included the animal's tongue and 


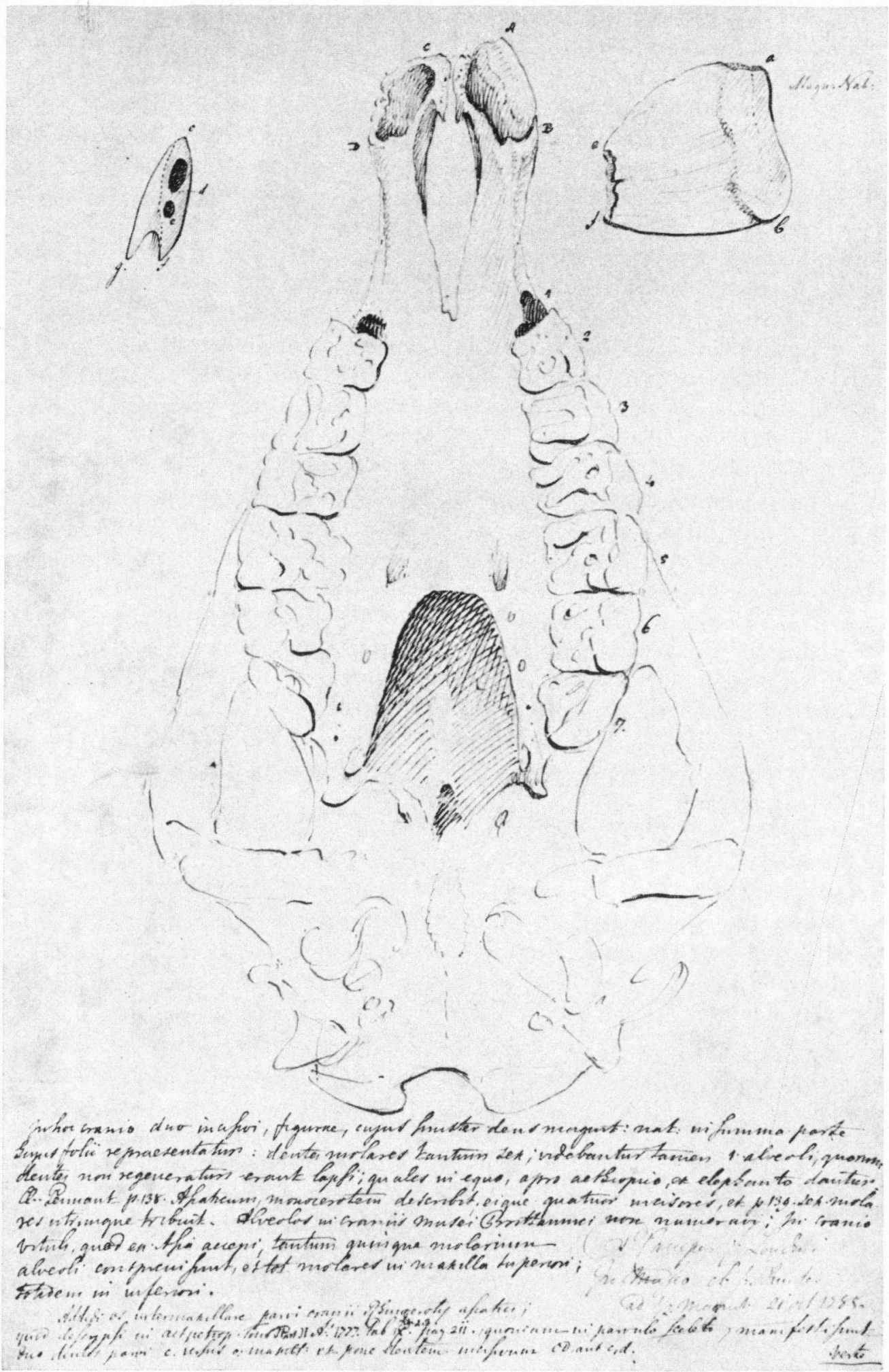

Fig. 4. The skull of an Indian rhinoceros (Rbinoceros unicornis) in the collection of John Hunter in London, drawn by Cam per on 21 October 1785. (Library of the University of Amsterdam, department of manuscripts, A X.) 
feet. 24 On 19 February 1787, Camper wrote to Banks 25: "You have already been informed, I believe, that I have got from Java, a prodigious fine head of the asiatick rhinoc. with one horn; I have sent my engraver the Propl. and frontview of it, and of the African Rhinos: reduced to $1 / 4$ to have them engraved upon the same plate. ...The asiatick specimen is finer, and more compleat than that of Mr. John Hunter." Clearly, it was this specimen which Camper had engraved by Vinkeles; an illustration which will be discussed below (section 8).

9, 10. Van der Steege wrote to Camper on 1 October 178726 that he was sending on the Wijnanda Lubberta two boxes including "two complete heads of the rhinoceros. To obtain these, I sent four of my slaves with some natives to the mountains and they brought me these beautiful heads after more than a month in the jungle. They belong to an old female and a young male, which is still changing its teeth like the biggest crocodile." In the first box, there were also the "two front legs of the male, and the hind legs and the neck of the female rhinoceros" and the "tongue of the small rhinoceros" (see no. 7 above). The second box contained "the lower parts of the rhinoceros legs which are dry in the box. The tongues of both and the sexual organ of the male one." The arrival of this shipment, probably during 1788 , is not mentioned in the available correspondence, but Camper's (1791: 50) remarks about four heads seems to indicate their safe receipt. Camper (1791: 50) presented one head, probably one of these two, to his "Freunde Sömmering in Mainz." 27

\section{ADDITIONAL OBSERVATIONS IN 1787}

In the passage cited in the introduction, Camper (1793) mentioned a "Fortsetzung meiner Abhandlung" to be sent to the Academy in St. Petersburg. Elsewhere, Camper (1791: 61) claimed to have "in dem Zusatze zur Abhandlung über das Afrikanische Nashorn in den Petersburg. Acten die wahre Kennzeichen beyder Arten vollständig abgehandelt, welches hier zu wiederholen unnöthig wäre, weil sie im 4ten Band meiner kl. Schriften zu finden sind." This paper certainly never appeared, neither in the periodicals of the Academy in St. Petersburg, nor in Camper's "Kleine Schriften", of which only 3 volumes have ever been published.

There is, however, a manuscript entitled "Additamentum ad dissertationem de cranio Rhinocerotis Africani gemino cornu de: Act. Petrop: Tom. I pag. 193 pro $A^{\circ} 1777$ datam ad 26: Octob. 1776." 28 While it is not dated, internal evidence clearly indicates that it must have been written in 1787. 29 In this manuscript, Camper reviewed the literature which appeared after 1776, and he discussed the observations which led him to some extended conclusions, as follows:

a. The Asian rhinoceros skulls examined in the British Museum lacked the intermaxillaries, but the lower jaws had 2 large incisors and the sockets of two more in between.

b. The adult rhinoceros skull from Asia in Hunter's collection showed the same arrangement as those in the B.M., while there were 2 incisors in the intermaxillaries of the upper jaw.

c. The skeleton of the young rhinoceros sent from Java (no. 7) showed two large and 2 small teeth in the upper jaw.

d. The skull of the adult rhinoceros from Java (no. 8) had the same set of teeth as Hunter's specimen.

Camper now asserted that he was more certain about the suggestion earlier published by Pallas (1780: 211) concerning the presence of teeth in the anterior parts of both jaws. He was convinced enough to include the arrangement of the teeth in his diagnosis of the only two species he still recognized: the Aethiopian or African, with a double horn, without any incisors and without folds on the body, from the Cape; and the Asiatic, singlehorned, with skin folds on the body, neck and thighs, provided with 2 broad incisors in the upper jaw and 4 in the lower jaw.

Camper wrote a summary of these results to Joseph Banks in a letter of October 1787: 30

"Mr. Pennant [1781: 136-140] was the first, who divided these animals into two species; 


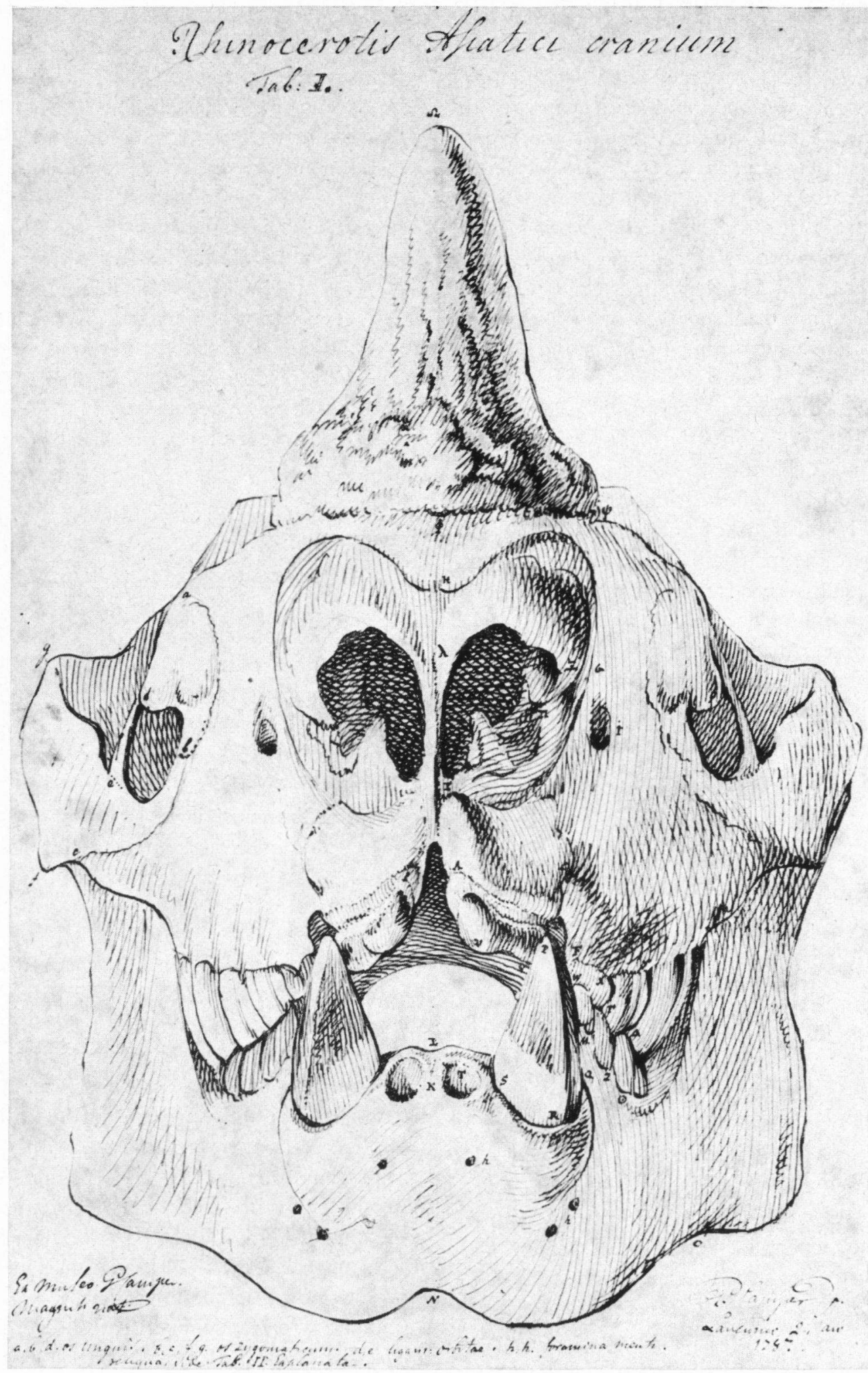

Fig. 5. Front view of the rhinoceros head sent from Java by Van der Steege (no. 8), drawn by Camper on 24 January 1787. (Library of the University of Amsterdam, department of manuscripts, A X.) 
as I did a long while ago, before I was acquainted with his book on quadrupeds, but only by conjecture.

The African has naturally and constantly two horns and never any folds on its body; no cutting teeth, seven grinders, on each side of the jaw, 28. in all.

The Asiatic has only one horn, two cutting teeth in the upper maxilla, and seven grinders on each side. Pennant mentioned only six, tho there are seven not only in the specimen now in my possession, but likewise in that of $\mathrm{Mr}$. John Hunter's. The os intermaxillare is very large and contains two incisivi in the young ones, the second is shed and never grows out again, belonging to the supernumerary teeth, which are common to a great number of quadrupeds. $[. .$.$] In the skeleton of the young$ Rhinoceros, which was sent to me by the same Dr. Van der Steege these two are very visible, the alveoli of these I have already described in the Comment. of the Imp. Acad. of Petersburgh. 31 The maxilla inferior contains on each side likewise seven grinders, and four cutting teeth, two very long and large, almost triangular in the middle and sharp on the sides: two smaller round and pointed in the middle."

Camper added some observations communicated to him by Van der Steege about the use of the incisors as a weapon by the rhinoceros, the softness of its tongue, its folded skin and the high value of the small middle incisors to the Javanese. The last fact would help to explain why the skulls sent from Java always lacked these teeth. 32

\section{THE ENGRAVING BY VINKELES}

It was now quite undeniable that the African Rhinoceros differed in essential respects from the Asian species. This conclusion was important enough to Camper to show the two species in a privately published engraving of 1787 . The plate was engraved by $R$. Vinkeles and dedicated to Jacob van der Steege. 33 It depicts the skull of the African rhinoceros (no. 1) from the front and from the side, and the adult skull from Java (no. 8) in the same positions, both reduced to a quarter. Preliminary drawings for this engraving are shown in figs. 1,5 and 6 . The engraving was not for sale, but Camper donated them to friends and institutions. ${ }^{34}$ Later, Blumenbach (1796, pl. VII) used the engraving with an acknowledgement of its source.

\section{DID CAMPER DISCOVER THE JAVAN RHINOCEROS?}

We have now covered all evidence found in Camper's publications, letters and manuscripts which could help to solve the above question. It has been proven that Camper examined specimens from Africa, India and Java, and was therefore in a position to distinguish the three species. However, in none of the studies discussed here, with the exception of the posthumously published letter to Pallas, we could discover any trace of evidence that he was aware of or even suspected a specific difference between the Indian and the Javan rhinoceroses. His last reference to his rhinoceros studies was in a letter to the Imperial Academy in St. Petersburg, dated 27 April 1788. 35 There too no mention is made of a distinction between the two Asian species. In order to account for the curious remark in Camper (1793) we can do nothing but suggest that it originated in the period 27 April 1788-7 April 1789, the day when he died. It was in that period that Camper received the last shipment from Java (specimens 9 and 10). It is possible then that Camper arrived at new conclusions after 27 April 1788. Unfortunately nothing more can be said at this juncture as there is no further evidence in any of Camper's published or unpublished works.

\section{CAMPER'S SPECIMENS AFTER HIS DEATH}

When Petrus Camper died in 1789, his entire collection was left to his son Adriaan Gilles Camper (1759-1820). He compiled some catalogues of this museum which was kept in his country estate Klein Lankum near Franeker (A. G. Camper, 1809, 1811). ${ }^{36}$ The enumeration of the rhinoceros specimens indicates that we have covered all material in Camper's collection and that most was still present when the catalogues were written: 


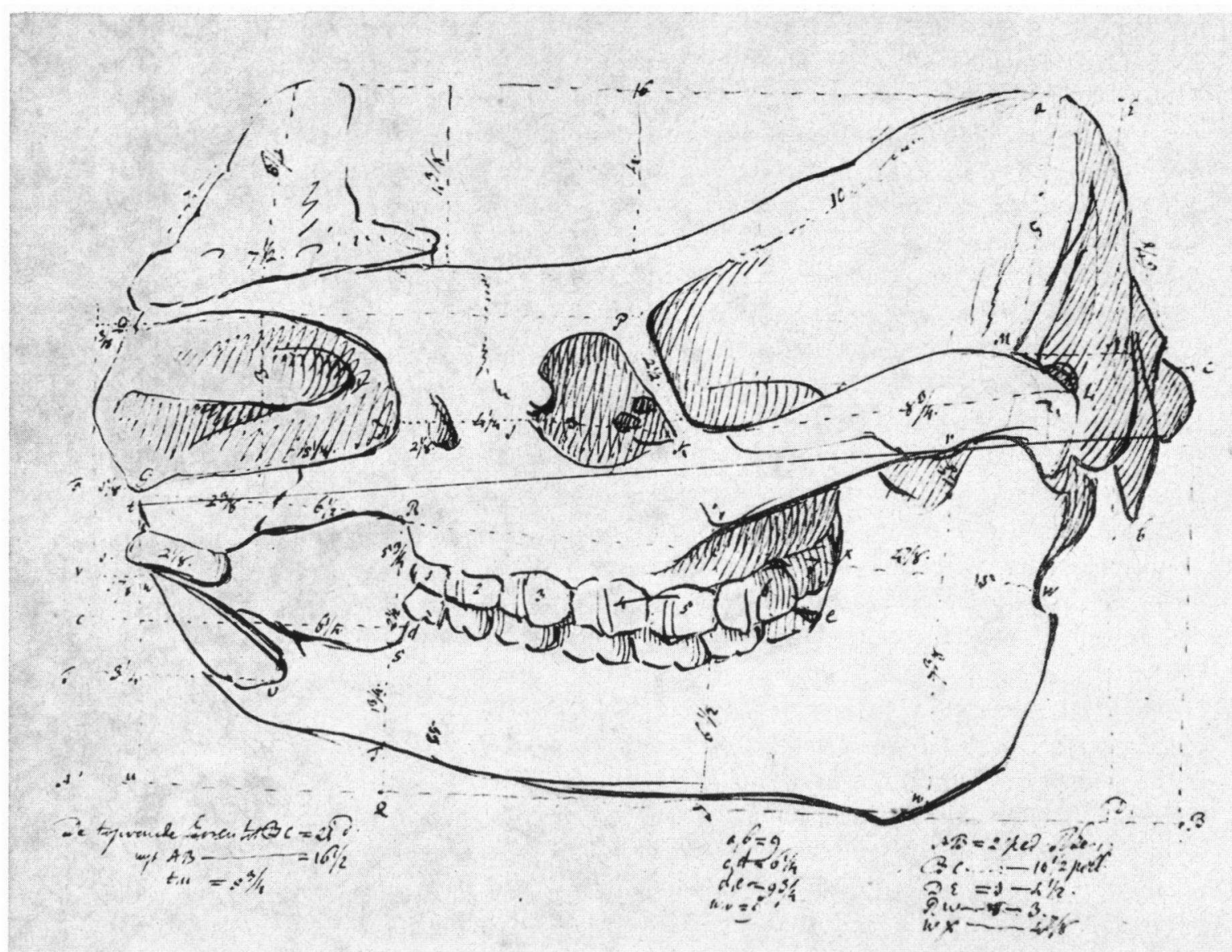

Fig. 6. The skull of the rhinoceros shown in fig. 5, also drawn by Camper. (Library of the University of Amsterdam, department of manuscripts, A X.)

"62. Le squelette d'un très-jeune rhinocéros d'Asie; sa hauteur est de six décimètres; la longueur de huit décimètres.

63. Quatre crânes du rhinocéros d'Asie; ils diffèrent pour l'âge et le sexe.

64. Le crâne d'un rhinocéros à double corne, du Cap.

65. La peau bourrée du même animal.

66. Plusieurs os du nez de rhinocéros d'Afrique avec les cornes; il s'en trouve qui sont longues de huit décimètres.

67. Différentes parties de squelettes, les vertèbres cervicales, une partie du thorax et des extremités antérieures et postérieures de plusieurs rhinocéros de Java.

68. La collection des pièces en liqueur comprend la langue, la verge, etc."

(A. G. Camper, 1811: 19).
In 1820 , when $A$. G. Camper died, the collection was transferred to the University of Groningen where it was divided between the Theatrum Anatomicum and the Cabinet of Natural History. The latter museum was destroyed in a fire in 1906. The specimens from the anatomical theatre were later dispersed among several institutes of the university. They were shown in 1939 in a memorial exhibition (Anonymous, 1939). Only one specimen mentioned in this paper is listed there, as "two rhinoceros horns of a Rhinoceros bicornis" (Anonymous, 1939: 36, no. 119), but these horns belong to two different individuals of $R$. unicornis (fig. 7).

Two other skulls may have been preserved although they are at present irretrievable. One skull was sent by Camper to Sömmerring in Mainz, as we have seen above (no. 9, 10). Another skull 
was donated by A. G. Camper to Georges Cuvier in Paris as we shall elucidate in the next section. This skull of Rbinoceros sondaicus was placed by Cuvier in the collections of the Muséum National d'Histoire Naturelle in Paris. It may still be there although two recent catalogues of the specimens of the Javan Rhinoceros in world museums only list two skulls (from Indo-China), one mounted skin from Java and 3 complete skeletons of unknown origin in the Paris museum (Loch, 1937; Barbour \& Allen, 1932).

\section{CUVIER'S CLASSIFICATION OF CAMPER'S RHINOCEROS SKULL}

As Georges Cuvier (1769-1832) often referred to the Javan Rhinoceros skulls owned by Petrus Camper, it is important to investigate how these specimens influenced his ideas. His first attempt to classify the rhinoceroses is found in Geoffroy \& G. Cuvier (1795), where three living (and one fossil) species are distinguished: the African rhinoceros described by Camper (1780), the ordinary Asian single-horned rhinoceros, and another one-horned species. The last species is based on a figure drawn by Camper but published by Pallas (1780, pl. IX fig. II), which shows the anterior part of the upper jaw of a rhinoceros from Java (no. 6). There are two sockets in this part of the jaw, the anterior one much larger than the one behind it, which were not found in the other single-horned species (fig. 2). A few years later, Cuvier (1797, 1798), more carefully, only distinguished two species, $R$. unicornis and $R$. bicornis, while he indicated the possible distinction of the animals described by Bruce (1790) and by Bell (1793) and the one by Camper. 37

In 1799, Cuvier began to correspond with Adriaan Gilles Camper (Theunissen, 1980). 38 These letters often included questions about the rhinoceros specimens formerly owned by Petrus Camper. On 12 February 1801, A. G. Camper 39 wrote that he had decided to donate one skull of the rhinoceros from Java to Cuvier. While acknowledging its safe arrival in Paris, Cuvier 40 added that "la tête de Rhinocéros me parait, à une légère inspection, d'une espèce différente. J'y regarderai avec plus d'attention, et je vous

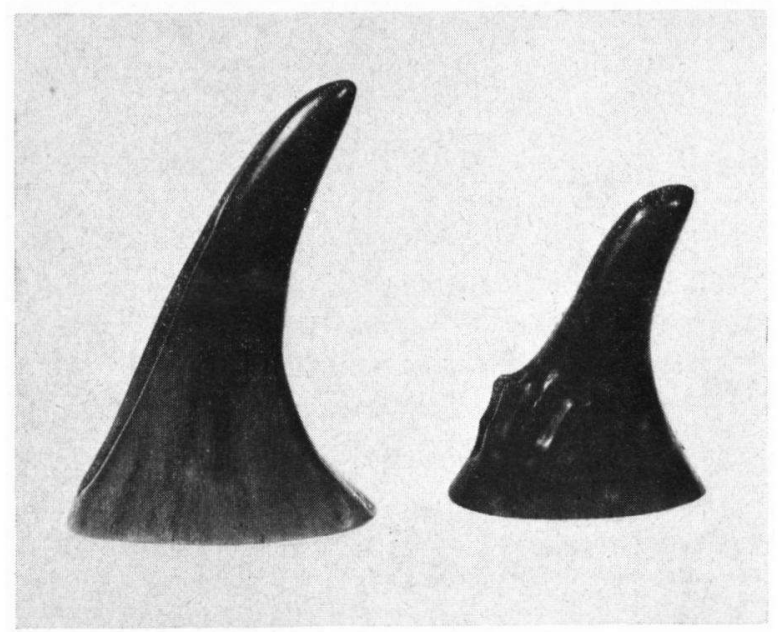

Fig. 7. Two horns of Rhinoceros unicornis from the collection of Petrus Camper, being the only surviving specimens, preserved in the Museum of the Laboratory of Anatomy and Embryology, University of Groningen.

enverai le dernier résultat." There is no doubt that Cuvier received the skull described above as no. 8.41

Cuvier (1812a) presented an extensive description of the skeleton of the Indian rhinoceros which died in the Versailles menagerie in 1793, compared with "la tête d'un rhinocéros plus jeune, que notre Muséum doit à la générosité de $M$. Adrien Camper, et qui est précisement celle qui a servi à la planche de son illustre père." 42 The older Versailles skull was a quarter higher than the other although they had the same length (Cuvier, 1812b: 33). For a good understanding of Cuvier's classification at this point, it is necessary to look somewhat more closely at his notes on the incisors of the rhinoceros. As in 1795, he observed the presence of a small tooth on the outside of the large incisor in the upper jaw of the very young specimen figured earlier by Camper (in Pallas, 1780, pl. IX fig. II). He found a similar tooth on one side only in the upper jaw of the old Versailles specimen (fig. 8), which indicated to him that this character was not linked with age. 43 However, "notre unicorne d'âge intermédiaire", i.e. the skull sent by A. G. Camper, did not even show a trace of the socket of such a tooth. Cuvier then asked: "Y auroit-il en Asie espèces distinguées par la forme de la tête et par le nombre des incisives, mais dont l'une au moins 


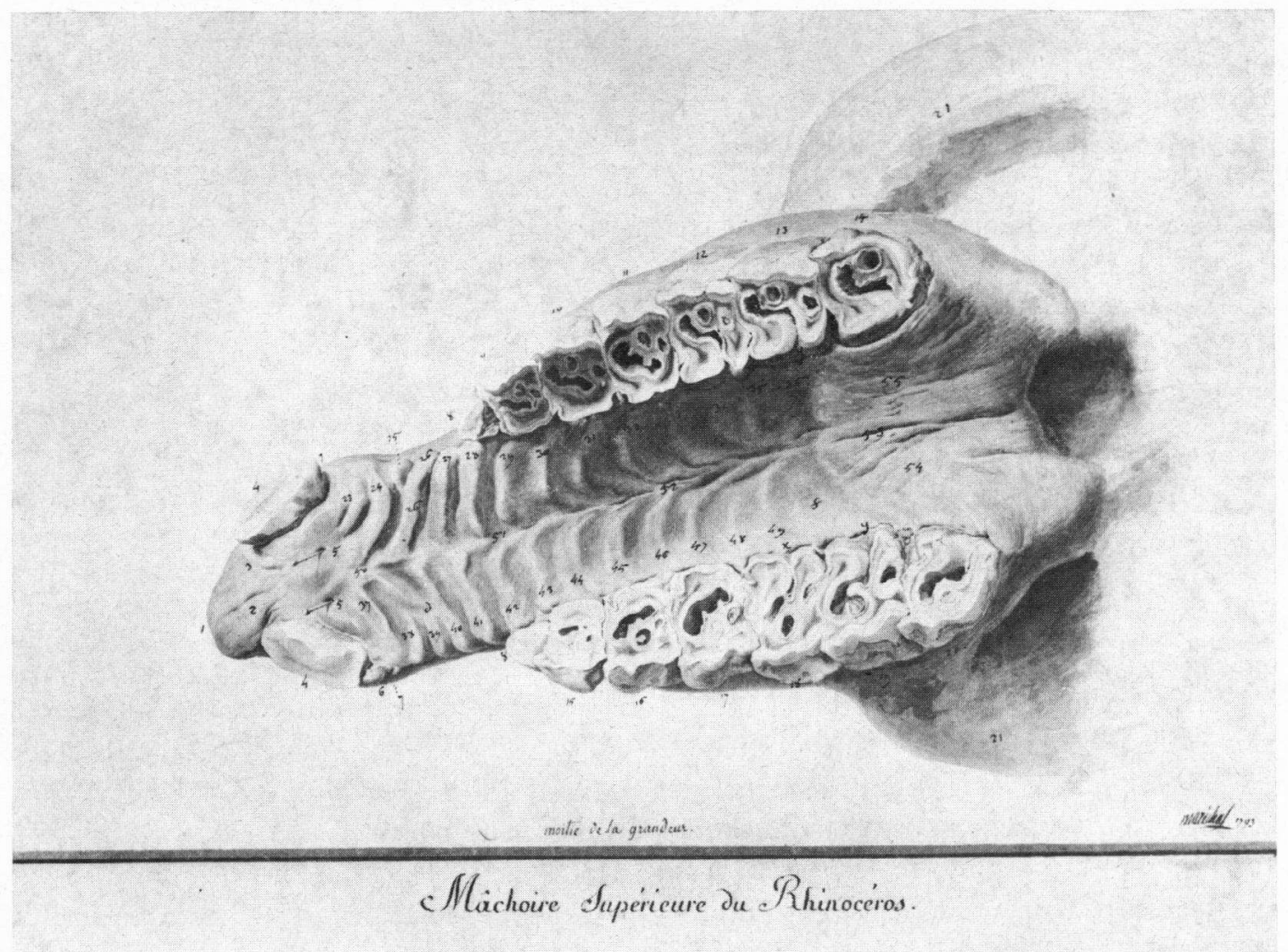

Fig. 8. Upper jaw of the Indian rhinoceros (Rbinoceros unicornis) which lived in the Versailles Menagerie (1770-1793), drawn by Maréchal in 1793. Note the small tooth labelled " 6 " behind the right incisor. (Vélin vol. 60 no. 66 , Muséum National d'Histoire Naturelle, Bibliothèque Centrale, Paris.)

seroit indifféremment unicorne ou bicorne?" (1812b: 13). He hesitatingly suggested that there are two Asian species of rhinoceros: one with a high skull provided with 2 incisors in both sides of the upper jaw (based on the Versailles rhinoceros and the specimen figured by Pallas); and another with a lower skull, without the second upper incisor (based on the one-horned specimen donated by A. G. Camper and the double-horned animal described by Bell in 1793). 44 Cuvier (1812b: 14) thought it likely that Camper had reached that same conclusion, which would have led to the note in Camper (1793).

These points are discussed by De Blainville. (1817: 165-166), who objects that the number of horns is too peculiar to be accidental in the rhinoceros. He assumed "que la crâne dont il est question, et dont on ne connoît en France que la

figure, n'est qu'une variété de l'unicorne." 45 This is the last of the discussions in which the specimen of Camper played an important part, because in 1821 the Muséum in Paris received a skeleton of a single-horned rhinoceros collected by Pierre Diard (1794-1863) in Indonesia. On the basis of that specimen, the Javan Rhinoceros was definitively distinguished from the other Asian species and Camper's specimen (no. 8) was also allocated to this new species (De Blainville, 1846: 72-73; Cuvier, 1822: 20-29).

\section{ABBREVIATIONS}

BM hss. IFFC UBA UBL
British Museum, London manuscript (with number) Institut de France, Paris: Fonds Cuvier Libraty of the University of Amsterdam Library of the University of Leiden 


\section{NOTES}

1. The third recent Asian species, the double-horned Sumatran Rhinoceros, Dicerorbinus sumatrensis (Fischer, 1814) can be excluded from the discussion. It was first observed by Bell (1793) and its occurrence was unsuspected by Camper and his contemporaries.

2. Jardine (1836: 181) claimed that "De Blainville gave to another rhinoceros which he characterized from the skull, the title of $R$. Camperii but the species remains in uncertainty." De Blainville discussed a "rhinocéros de Camper" but probably never proposed a binomen.

3. The views of Georges Cuvier and De Blainville are further discussed in section 11.

4. A Latin-English edition of Bontius's book was edited by Van Andel (1931). The account of the rhinoceros is presented in a German translation by Sody (1959: 127-128, 187-188).

5. Piso's (1658: 52) note states: “Quapropter elegantem \& genuinam hanc belluae effigiem ad vivum in Indiis depictam favore praestantissimi Viri, Ioannis Wtenbogaert, in Amstelodamo Hollandiae Quaestoris, hic offero." An English translation of 1769 , used by Van Andel (1931), translates "in Indiis depictam" into "drawn in India", but "in the Indies" is more accurate.

6. The illustrations are very crude. Besides the "saddle", the animal in the upper figure also shows a dewlap formed by the skin folds in the throat region, typical of $R$. unicornis. The head in the lower figure is one-horned but otherwise without characteristics.

7. Letter unknown. The date is recorded in a return letter by Van Plettenberg in Cape Town to Camper dated 28 February 1772 (UBA, hss. X 114).

8. Camper used Rhijnlands measure: 1 foot equals $31.4 \mathrm{~cm}$, 1 duym $2.62 \mathrm{~cm}$.

9. Johannes Paulus Hoffmann was a former student of Camper, he got his M.D. at Groningen University in 1766. Afterwards he became physician in Batavia.

10. Some time between 1771 and 1774, Camper borrowed a collection of thinoceros plates compiled by James Douglas in 1739 (Rookmaaker, 1978b). Camper nowhere referred to this collection in his published work, although its use was acknowledged in a note in the manuscript of Camper's book (1782): "aan den Heere Hunter heb ik behalven deeze nog de verplichting van de geheele verzaameling Prenten en afteekeningen van den Rhinoceros, uyt het kab. van Douglas ter leen gehad te hebben" (UBL, hss. BPL 247/106, fol. 7 recto).

11. Camper drew it on 21 April 1779: "Fragmentum maxillae inferioris rhinocerotis adulti ex Museo Academiae Lugdunis Batavae" (UBA, hss. A X). Probably some time later, Camper added that it was an African rhinoceros because there were no incisors: "Est Africani, nam incisivos non habet, adeoque bicornis." The jaw shows just 3 molars on each side, the last one on the right side in the process of eruption. It is, therefore, most unlikely that the specimen is adult.

12. Lacroix (1977: 13-19) described the early history of the Versailles rhinoceros. It arrived in the menagerie on 11 September 1770 and died there in September 1793. Camper's drawing of its head and penis is preserved (UBA, hss. $A \mathrm{X}$ ) and has some morphological notes on the verso.
13. Sody (1959: 132) is in error when he writes: "Andererseits [Acta Acad. Scient. Imper. Petropolitanae, 1777, II, Tab. IX] hatte Camper wahrscheinlich bereits solch einen Schädel von $R h$. sondaicus abgebildet, ohne es recht selbst zu wissen." Plate IX only shows small parts of the Javan skull (figs. 2, 3), which were drawn by Camper but published by Pallas (1780).

14. The French translation of $\mathbf{1 8 0 3}$ also has some additional footnotes, but not those present in the German work, nor any pertinent to our theme.

15. Camper referred to plates in Parsons (1743), Albinus (1747) and Buffon \& Daubenton (1764). All these are illustrated in Rookmaaker (1973).

16. The number of teeth is not constant in the rhinoceros. $R$. sondaicus usually has 3 molars and 3 premolars in each side of both jaws, one incisor in both sides of the upper jaw, and 2 incisors in both sides of the lower jaw. Diceros bicornis has 4 premolars and 3 molars in each side of both jaws; sometimes one premolar lacks, and both jaws can show one or two vestigial incisors (Hitchins, 1978: 72).

17. Camper made two drawings of thinoceros specimens in the British Museum (UBA, hss. A X).

18. One is shown in fig. 4. Another drawing is entitled: "Rhinocerotis Asiaticis unico cornu maxilla inferior, magnit: nat. - P. Camper Londini in Museo J. Hunter, ad 21 Oct. 1785" (UBA, hss. A X). John Hunter's collection went to the Royal College of Surgeons of England. Their catalogue prepared by Flower \& Garson (1884) listed 3 specimens of Rbinoceros as "Hunterian":

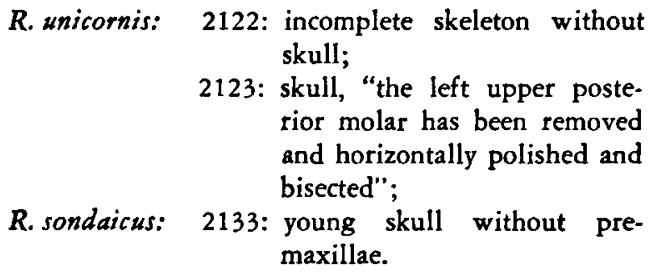

Camper may have seen no. 2123. The young skull of $R$. sondaicus 2133 is one of the few osteological specimens to survive the bombings of 1941 (Ms. E. Allen, Curator of the College, in litt. 27 April 1982).

19. Camper to Banks, 8 June 1786: BM, Add. MS. 8096, fols. 261-262.

20. Van der Steege to Camper, 1 October 1787: UBA, hss. $\mathrm{X}$ 133a. Quotations translated from the Dutch.

21. Van der Steege to Camper, 16 November 1785: UBA, hss. A X.

22. Camper to Banks, 8 June 1786 (note 19) and 18 June 1786: BM, Add. MS. 8096, fol. 408.

23. Camper's "Additamentum" (see section 7 and note 28), p. 15: "Accepi media aestate anni praeterlapsi 1786 alterum petriosum munus ab eodem D.V.D. Steege Cranium scilicet integrum Rhinocerotis Asiatici adulti cum unico Cornu, et ossis hyoidis conservatione. Lingua ac pedis digiti, trini splanchni [?] condita erant addita."

24. According to Camper's "Additamentum", see note 23.

25. Camper to Banks, 19 February 1787: BM, Add. MS. 8096, fols. 411-412.

26. Van der Steege to Camper, 1 October 1787: UBA, hss. X133a. 
27. A catalogue prepared shortly after the death of Samuel Soemmerring by his son Wilhelm, "Catalogus Musei anatomici quod collegit Samuel Thomas de Soemmerring" Frankfurt am Main, 1830, lists in part II (dry specimens), p. 184 no. 180 a "cranium Rhinocerotis Asiatici." Probably the specimen no longer exists. (Information kindly provided by Dr. Franz Dumont, Soemmerring-Forschungsstelle, Akademie der Wissenschaften und der Literatur, Mainz, in litt. 22.6.1982).

28. UBA, hss. Complementa Varia IV A 112, pp. 13-18. Camper sent these and additional observations on animals previously described by him to the Imperial Academy in St. Petersburg. For unknown reasons they were never published (Camper to Imperial Academy 27 April 1788, original in the Archives of the Academy, a copy is in the Rijksmuseum Boerhaave, Leiden).

29. Camper twice referred to "anni praeterlapsi 1786", as in note 23.

30. Camper to Banks, not dated but received by Banks on 10 October 1787: BM, Add. MS. 8096, fols. 413-414.

31. The skeleton (no. 7) was received in 1786 , and nothing was published about it between this date and October 1787. Camper probably referred to his description of the alveoli of another Javan skull (no. 6) included in the paper by Pallas (1780, pl. IX figs. II, III).

32. These teeth were used as amulets by the Javanese, possibly also by other people in South-east Asia. Martin (1980), unacquainted with most pertinent literature, does not mention this in his historical chapter, but states not to have discovered this use during his study trip in S.E. Asia.

33. The engraving and some preliminary drawings are preserved: UBA, hss. A X (figs. 5, 6) and UBL, hss. BPL $247 \mathrm{I}$ omslag 20 (fig. 1).

34. For instance, Camper sent copies to Banks, the Royal Society and the British Museum in London (Camper to Banks, 27 September 1788: BM, Add. MS. 8097, fol. 23).

35. See note 28 . With regard to the rhinoceros he refers to his new observations sent to the Academy as "lucubrationes meas... de Rhinocerote Aethiopico et Indico...".

36. A shorter list of the material is found in A. G. Camper's letter to Cuvier, 4 June 1800: IFFC, 222 (6).

37. The rhinoceros drawn by Camper is not mentioned in the published abstract of Cuvier's lecture (1797). Cuvier wrote to A. G. Camper about this on 17 May 1800 (UBA, hss. X $48 \mathrm{e}$ ): "les feuilles publiques auront altéré ce que j'ai lu à l'Institut sur les Rhinocéros; j'y ai dit seulement qu'outre les trois espèces connues, il parait par les voyageurs, si leurs descriptions sont fidèles, qu'il y en a encore deux autres, le bicorne de Bruce d'Abysinie, et celui de Bell, à Sumatra. Jajoutais que la description donnée par Mr. votre père de la tête d'un jeune unicorne, n'était point conformé, quant aux dents antérieures à la tête adulte que nous possédons, et qu'il était très possible que ce fût là encore une espèce particuliète."

38. The correspondence between $\mathbf{A}$. G. Camper and Cuvier was analyzed by Bert Theunissen, "Een studie over A. G. Camper als zoöloog aan de hand van zijn korrespondentie met G. Cuvier", an unpublished master's thesis prepared at the Biohistorical Institute, University of Utrecht. The results are summarized in Theunissen (1980).
39. A. G. Camper to Cuvier, 12 February 1801: IFFC 223 (39).

40. Cuvier to A. G. Camper, not dated: UBA, hss. X $49 \mathrm{~d}$.

41. This is not only evident from Cuvier's own statements. P. Camper said that some ligaments were still preserved, and indeed some are shown in the plate engraved by Vinkeles (see also figs. 1 and 6). Cuvier (1812b: 12) wrote that "nous l'avons débarrassé de ses ligamens et de sa corne, pour le faire dessiner de nouveau."

42. A copy of the engraving had been sent to Cuvier by A. G. Camper, of. Cuvier to Camper, not dated (note 40).

43. This tooth is clearly depicted in a drawing of the "Mâchoire supérieure du Rhinocéros" drawn by Maréchal in 1793 (Vélins du Muséum National d'Histoire Naturelle, vol. 66 no. 70) (fig. 8).

44. This classification is also found in Cuvier (1816), where he distinguished between Rhinoceros bicornis, $\boldsymbol{R}$. indicus and $\boldsymbol{R}$. sumatranus. There is no mention of Camper's specimen.

45. It is remarkable that De Blainville had the impression that there was the engraving only, and not the skull itself.

\section{REFERENCES}

Albinus, B. S., 1747. Tabulae sceleti et musculorum corporis humani. (Iohannem et Hermannum Verbeek, Lugduni Batavorum).

ANDEL, M. A. van (ed.), 1931. Bontius on tropical medicine. Opuscula selecta neerlandicorum de arte medicina, 10: i-lxxiv, 1-459.

Anonymous, 1939. Catalogus van de tentoonstelling ter herdenking van den 150 sten sterfdag van Petrus Camper 1722-1789 gehouden te Groningen van 30 april tot 7 mei 1939: 1-50 (J. B. Wolters, Groningen).

Barbour, T. \& G. M. Allen, 1932. The lesser one-horned rhinoceros. J. Mammal., 13: 144-149, pl. XI.

BELL, W., 1793. Description of the double-horned rhinoceros of Sumatra. Phil. Trans. R. Soc., 1793: 3-6, pls. II-IV.

Blainville, H. DE, 1817. Lettre de M. W.-J. Burchell sur une nouvelle espèce de rhinocéros, et observations de $M$. de Blainville sur les différentes espèces de ce genre. J. Phys. Chim. Hist. nat., 85: 163-168, 1 pl.

- , 1846. Des rhinocéros (Buffon) (G. Rhinoceros, L.). In: Ostéographie ou description iconographique comparée du squelette et du système dentaire des mammifères récents et fossiles pour servir de base à la zoologie et à la géologie, III: Quaternatès: 1-232 (J. B. Baillière et fils, Paris).

BlumenBACH, J. F., 1796. Abbildungen naturhistorischer Gegenstände Nro. 1-100 (Heinrich Dieterich, Göttingen).

Bonrius, J., 1642. De medicina Indorum Lib. IV: [i-vi], 1-212, [i-iv] (Franciscus Hackius, Lugduni Batavorum).

BruCE, J., 1790. Travels to discover the source of the Nile, in Egypt, Arabia, Abyssinia, and Nubia, 5: [1-3], i-iv, iii-xiv, 1-230, [1-10] (J. Ruthuen, Edinburgh).

Buffon, G. L. Leclerc de \& L. J. M. DAubenton, 1764. Histoire naturelle, générale et particulière, avec la description du Cabinet du Roi, 11: i-iv, 1-45,1 (I'Imprimerie royale, Paris). 
CAMrer, A. G., 1809. [Description of Camper's anatomical, geological and mineralogical cabinet at Klein Lankum near Franeker.] Jaarboeken der wetenschappen en kunsten in the koningrijk Holland, 1: 68.98 (Reprinted in: Almanak der Akademie van Groningen, 9 (1821): 12-56).

—, 1811. Description succincte du Musée de Pierre Camper: i-viii, 1-93 (Frères van Cleef, Amsterdam et la Haye).

Camper, P., i780. Dissertatio de cranio rhinocerotis Africani, cornu gemino. Acta Acad. Scient. Imp. Petropol., 1 (pars post): 193-209, pls. V-VIII.

,- 1782 . Natuurkundige verhandelingen over den orang outang; en eenige andere aapsoorten. Over den rhinoreros met den dubbelen horen; en over het rendier: [i-iv], 1.235, [i-ii] (Erven P. Meijer en G. Warnars, Amsterdam).

- 1791. Naturgeschichte des Orang-Utang und einiger andern Affenarten, des Afrikanischen Nashorn, und des Rennthiers. Ins Deutsche übersetzt und mit den neuesten Beobachtungen des Verfassers herausgegeben von J. F. M. Herbell: 1-224 (J. C. Dänzer, Düsseldorf).

- , 1793. Aus einem Briefe des nun verstorbnen h. Professors Camper aus Leuwarden, aus dem franz. Neue Nordische Beyträge, 6: 249-250.

- 1803. Oeuvres de Pierre Camper, qui ont pour objet l'histoire naturelle, la physiologie et l'anatomie comparée, I: i-civ, 1-392 (H. J. Jansen, Paris).

Cuvier, G. L. C. F. D., 1797. Sur les différentes espèces de rhinocéros. Bull. Soc. philom. Paris, Juin 1797: 17.

- , 1798. Tableau élémentaire de l'histoire naturelle des animaux: i-xvi, 1-710 (Baudouin, Paris).

- 1806. Sur les rhinocéros fossiles. Annls. Mus. Hist. nat. Paris, 7: 19-52, pls. I-IV.

— 1812a. Description ostéologique du rhinocéros unicorne. In: Recherches sur les ossemens fossiles de quadrupèdes, où l'on rétablit les caractères de plusieurs espèces d'animaux que les révolutions du globe paroissent avoir détruites, 2 (3): 1-21, 4 pls. (Déterville, Paris).

- 1812b. Sur les ossemens fossiles de rhinocéros. In: Recherches sur les ossemens fossiles de quadrupèdes [...], 2 (4): 1-33, 3 pls. (Déterville, Paris).

$\longrightarrow$ [1816]. Le règne animal distribué d'après son organisation, pour servir de base à l'histoire naturelle des animaux et d'introduction à l'anatomie comparée, 1: i-xxxvii, 1-540 (Déterville, Paris).

- 1822. Recherches sur les ossemens fossiles, où l'on rétablit les caractères de plusieurs animaux dont les révolutions du globe ont détruit les espèces. Nouvelle édition, 2 (1): [i], 1-232 (G. Dufour et E. D'Ocagne, Paris et Amsterdam).

Flower, W. H. \& J. G. Garson, 1884. Catalogue of the specimens illustrating the osteology and dentition of vertebrated animals, recent and extinct, contained in the Museum of the Royal College of Surgeons of England, 2: i-xliii, 1.779 (Royal College of Surgeons, London).

Geoffroy-St. Hilarre, E. \& F. Cuvier, 1824. Rhinocéros de Java. In: Histoire naturelle des mammifères, avec figures originales, coloriées, dessinées, d'après des animaux vivants, 6: 1-2, pl. I (Blaise, Paris).

Geoffroy-St. Hilatre, E. \& G. CUVIER, 1795. Sur le rhinocéros bicorne. Magazin encycl., 1: 326-328.

GugGisberg, C. A. W., 1966. S.O.S. Rhino: 1.174 (André Deutsch, London).
Hitchins, P., 1978. Age determination of the black rhinoceros (Diceros bicornis Linn.) in Zululand. S. Afr. J. Wildl. Res., 8 (2): 77-80, figs. 1-7.

JARDINE, W., 1836. The naturalists' library, 5. Pachydermes: i-xvi, 1-248 (W. H. Lizars, Edinburgh; S. Highley, London; W. Curry jun. \& Co., Dublin).

LACRoIX, J.-B., 1977. L'approvisionnement des ménageries et les transports d'animaux sauvages par la compagnie des Indes au XVIIIème siècle: 1-29, cyclostyled (Lorient).

Loch, C. W., 1937. Rhinoceros sondaicus, the Javan or Lesser One-horned Rhinoceros and its geographical distribution. J. Malay. Brch R. Asiat. Soc., 15: 130-149, pls. 3-4, 1 map.

MARTIN, E. B., 1980. The international trade in rhinoceros products: 1.83 (IUCN/WWF, Gland).

MrRCK, J. H., 1786. Troisième lettre sur les os fossiles d'éléphans et de rhinocéros qui se trouvent en Allemagne et particulièrement dans le pays de Hesse-Darmstadt, adressée à Monsieur Forster: 1, 1-29 (Imprimerie de la Cour et de la Chancellerie du S.A.S., Darmstadt).

MülLER, S. \& H. SCHLEGEL, [1845]. Bijdragen tot de natuurlijke historie der thinocerossen van den Indischen Archipel. In: C. J. Temminck ed., Verhandelingen over de natuurlijke geschiedenis der Nederlandsche overzeesche bezittingen, Zoölogie: 183-193, pls. XXX-XXXIV (S. \& J. Luchtmans \& C. C. van der Hoek, Leiden).

Nuyens, B. W. T. (ed.), 1939. Petri Camperi itinera in Angliam 1748-1785. Opuscula selecta neerlandicorum de arte medicina, 15: i-lix, 1-264.

Pallas, P. S., 1769. De ossibus Sibiriae fossilibus craniis praesertim rhinocerotum et buffalorum, observationes. Novi Comment. Acad. sci. imp. Petropol., 13: 436-477, pl. X.

- 1780. Additamentum. Acta Acad. Scient. Imp. Petropol., 1 (pars post): 210-212, pl. IX.

Parsons, J., 1743. A letter to Martin Folkes, Esq; president of the Royal Society, containing the natural history of the rhinoceros. Philos. Trans. R. Soc., 42: 523-541, pls. I-III.

Pennant, T., 1781. History of quadrupeds, 1 [1], i-xxiv, 1-566, [i-xii] (B. White, London).

PICARD, H. W. J., 1972. Masters of the castle: a portrait gallery of the Dutch commanders and governors of the Cape of Good Hope, 1652-1795, 1803-1806: 1-231 (C. Struik, Cape Town).

Piso, G., 1658. De Indiae utriusque re naturali et medica, libri quatuordecim: [i-xxiv], 1-332 (L. \& D. Elzevirios, Amstelaedami).

RoOkmaAker, L. C., 1973. Captive rhinoceroses in Europe from 1500 until 1810. Bijdr. Dierk., 43 (1): 39-63, figs. 1.13.

-, 1978a. De neushoorn van 1741. Ons Amsterdam, 30 (1): 16.17, 3 figs.

- $1978 \mathrm{~b}$. Two collections of rhinoceros plates compiled by James Douglas and James Parsons in the eighteenth century. J. Soc. Biblphy nat. Hist., 9: 17-38, figs. 1-7. , 1981. Early thinoceros systematics. In: A. WHEELER \& J. H. PrICE (eds.), History in the service of systematics. Papers from the conference to celebrate the centenary of the British Museum (Natural History) 13-16 April, 1981: 111-118 (Society for the Bibliography of Natural History, special publication no. 1, London). 
- 1982. A story of horns: early views on rhinoceros classification. Zoonooz, San Diego, 55 (4): 4-10, 16 figs. SCHENKEL, R. \& L. SCHENKel-Hulliger, 1969. The Javan rhinoceros (Rh.sondaicus Desm.) in Udjung Kulon nature reserve, its ecology and behaviour, field study 1967 and 1968. Acta Tropica, 26 (2): 97-135, figs. 1-9.

SChreber, J. C. D. von, 1835. Die Säugthiere in Abbildungen nach der Natur mit Bemerkungen, fortgesetzt durch Johann Andreas Wagner, 6: i-xvi, 1-520 (Palm, Erlangen).
SODY, H. J. V., 1959. Das javanische Nashorn, Rhinoceros sondaicus, historisch und biologisch. Z. Säugetierk., 24: 109-240, pls. 5-8, figs. 1-7. (Original edition published in 1941, in Dutch.)

Theunissen, B., 1980. De briefwisseling tussen A. G. Camper en G. Cuvier. Tijdschr. Ges. Geneesk. Natuurw. Wisk. Techn., 3 (4): 155-177, 1 fig.

Received: 29 June 1982 